\title{
METHODOLOGY OF CASH FLOWS ANALYSIS
}

Miloš Pavlovići ${ }^{1}$ Čedomir Gligorić ${ }^{2}$, Jana Cvijić Rodić ${ }^{3}$

1, 2, 3 Belgrade Business and Arts Academy of Applied Studies, Belgrade, Serbia

Corresponding: milospavlovic84@hotmail.com ${ }^{1}$

Review article

Received: 27.02.2021; Accepted: 22.04.2021

Abstract: Cash flows are one of the main indicators of liquidity and slovency of the company. In practice, the Statement of cash flows is very often done as "following document" to Balance sheet and Income statement. This is wrong. The statement of cash flows can give the information to its users about the ability of the company to make cash. The balance sheet and Income statement, due to their accrual basis, are not saying anything about the cash flows of the accounting period, and that is why the Statement of cash flows is very important. A good analysis of this statement can be the basis and support to the process of decision making both for internal and external users of financial information. In this paper we are presenting the methodology of the Statement of cash flows report analysis. The subject of this paper is the analysis of the Cash Flow Statement. The aim of this paper is to point out the importance of reporting on cash flows and its information capabilities to users of accounting information.

Keywords: Methodology, Cash flows, Statement of cash flows, Analysis of cash flows.

\section{Introduction}

Doing business in modern conditions is very complex. In order for the decisions of the company's management and other stakeholders to be as good and efficient as possible, they need to have quality information. Management has a number of management accounting tools at its disposal to obtain certain information. However, external users are denied 
support for management accounting in making decisions, but financial statements are available to them. The analysis of the same leads to information that can significantly contribute to the business decisionmaking process.

In practice, the Balance Sheet and Income Statement are very often cited as the basic financial statements, while the impression is given that the Statement of Cash Flows is a secondary report. However, having in mind that the balance sheet and income statement, due to their accrual basis on which they are based, do not say anything about the cash flows of the accounting period, a special report on cash flows was created for that purpose. This report, in essence, tries to bridge the difference between the accounting (income - expenditure) and cash (cash receipts - issuance) results of activities, ie to provide additional insight into the sources and use of cash during the rearrangement of data contained in the company's financial statements of the observed period. For this reason, it can be said that the Cash Flow Statement is a very important source of information for decision makers, as it speaks to the liquidity of the reporting entity. If the information in this report is analyzed appropriately, it can significantly improve the business decision-making process.

\section{The beginning of cash flows reporting}

The history of cash flow reporting can be traced back to 1863. In that year, the Dowlais Iron Company had just recovered from the economic collapse but had no money to invest in new blast furnaces, despite making a profit. Director of the company is the lack of money to invest in new blast furnace despite the profits when explained through the financial report, which he called "a comparison of the balance sheet". This report is considered a precursor to cash flow reporting.

The year 1971 is the key year in the history of the development of cash flow reporting. This year in the USA, FAS B defined the rules that have become an obligation in accordance with the generally accepted accounting standards - US GAAP (Generally Accepted Accounting Principles), which referred to the obligation to compile a "Statement of cash flows" as mandatory financial report within the final account. However, studying the history of reporting on cash flows, we can see that the definition of "liquid assets" was not standardized for all economic entities. At that time, "net current assets (capital)" meant cash in cash, but the term was also used for assets that represents the difference between current assets and 
current liabilities. Due to that, there were big differences in the content of the mentioned report. [Meigs\&Meigs, 1999]

Such a report could not fully present the company's ability to generate cash and settle its debts on time, because, as we have already mentioned, cash flows do not have to coincide with profitability flows. The FASB's adoption of the provisions of the 1987 SFAS 95, Statement of Changes in Financial Position replaced the Statement of Cash flows, which, from the aspect of content and form, was more strictly defined in relation to the previous one. [Kintzele, 1990]

When it comes to European regulations, the International Accounting Standards Committee (IASC) adopted in 1977 the standard IAS 7 - Funds Flow Statement, which referred to the preparation of the Statement of Changes in Financial Position. The same standard was revised and published in 1992, under the heading Cash Flow Statement, which has been applied for the preparation and presentation of financial statements since 1994. Changing the center of gravity of information aimed to provide information on inflow and outflow of cash companies during accounting period and to allow projection of future cash flows, which is considered the central objective of financial reporting today.

\section{Definition, main elements and the importance of cash flows reporting}

A complete set of financial statements (balance sheet, income statement, statement of changes in equity, statement of cash flows and notes) provides a complete picture of the company's operations for a certain period of time. On the basis of the "traditional" financial statements, balance sheet and income statement, users can gain insight into the financial position and earning ability of the company, or the information contained in these reports are not sufficient to analyze and evaluate all relevant aspects of the financial operations of the company, bearing in mind that the business result expressed in the income statement is often not a reliable indicator of the company's ability to generate cash.

Namely, the income statement covers the effects of activities on an accrual basis and expresses them as the difference between income and expenses allocated to the appropriate accounting period. Due to a greater or lesser discrepancy between income and inflows, i.e. expenditures and outflows of money for a certain period, usually the result (profit) stated in the income 
statement (income and expenses ratio) does not correspond to the result determined on a cash basis (cash inflows and outflows). Therefore, in practice, it is not uncommon for companies to have a decrease in the cash balance and problems in maintaining current liquidity, despite the high net profit shown in the income statement. All this suggests that for successful cash flow management is necessary, the result was determined on an accrual basis (income statement) "adjusted" so that approximates the net cash inflows from the sales process activities. Precisely for these needs and developed a Statement of cash flows. [Stančić, 2006, 3]

A cash flow statement is a financial statement that allows you to track money coming in and out of business. It is an integral part of the business and a great tool for managers and investors that shows how changes in the balance sheet and income statement affect cash.

In essence, the Statement of Cash Flows explains what all during the reporting period affected the cash balance presented in the balance sheet at the beginning of the reporting period to arrive at a new cash balance at the end of the accounting period. [Libby et al., 2011, 638]

This Statement, in general, provide the following information to interested users [Kimmel et al., 2011, 15]:

- where the cash comes from during the reporting period,

- how cash was used during the period and

- what changes occurred in cash at the end compared to the beginning of the period.

Information from the Cash Flow Statement, if adequately linked to information from other financial statements (balance sheet, income statement and some general ledger accounts) helps the company's management but also external users to gain insight into the company's liquidity and solvency.

Without information on the company's cash flows, it is not possible to make adequate business decisions and thus maximize the success of the activities undertaken. Management uses this information to make a number of business decisions, starting from liquidity assessment, through dividend policy, to assessing success in achieving set goals and reviewing results from regular activities, investment and financing activities, as well as reviewing the contribution of each to business results. 
For external users, this information is used to assess the business performance, indebtedness, liquidity and solvency of the company. Investors, creditors, the state and other interested users thus gain insight into the profitability of the company and assess the risk of cooperation with that company.

Therefore, the Cash Flow Statement information helps users to:

- assess the company's ability to generate cash and cash equivalents and the company's ability and needs to use those cash inflows;

- assess the company's ability to influence the amounts and timing of cash flows in order to adapt to changing opportunities and circumstances;

- comparison of business activities of other companies, because cash flow excludes the possibility of using different accounting methods for the same transactions and events related to business activities, so that balance sheet policy measures cannot, at least not directly, affect the amount of reported net cash flow.

The company's management can use the above assessments in formulating:

- business policy,

- dividend policy and

- investment policies.

Statement of cash flows, providing information about the relationship between cash inflows and outflows, the areas in which investment inflows and on areas in which they are located need for cash, allows management to at a defined it in business policy recognizes the basic lines of its business activities, based on the amount of the realized net cash flow, the management formulates its dividend policy, and according to the sources of cash, it will determine the investment policy.

The Statement of cash flows provides investors with the information they need to:

- assess the company's ability to manage cash equivalents,

- considered the company's ability to generate positive future cash flows,

- assessed his ability to pay due obligations, 
- $\quad$ assessed the ability to pay dividends and interest and

- created an opportunity to anticipate the need for additional funding.

In addition, the Report may be used to explain the differences between the net profit or loss shown in the income statement and the net cash flows arising from operating activities.

\section{The definition of cash}

When we are talking about the Statement of cash flows, it is important to define cash as its main element. It can be said that there are three understandings of cash: [Djukić, 2005, 45]

- "Narrowly understood cash" - money available for everyday use in the form of legal tender such as metal and paper money in someone's wallet (population) or cash - the company's cash register and on the company's gyro or current accounts;

- "Widely understood cash" - which includes securities - securities purchased for resale or for commercial purposes, and securities purchased for long-term investment (participation shares) and time deposits with banks;

- "Almost cash" - cash equivalents - items that can be quickly and easily converted into known amounts of money but are in themselves neither "narrowly understood cash" nor "broadly understood cash". Cash equivalents include those securities that are not purchased for the purpose of resale or long-term investment of free funds. The most commonly considered cash equivalents are government bonds, government bills, etc.

Cash equivalents include assets: [Libby, 2011, 638]

- which is easy to convert into known amounts of cash and

- where there is a small risk that their value will change due to a change in the interest rate.

The concept of cash and cash equivalents is defined differently within individual national standards. The Financial Accounting Standards Board - FASB has defined in SFAS 95 - Statement of Cash Flows, Cash and Cash Equivalents as follows:

According to IAS 7, cash includes cash and demand deposits. Cash equivalents are short-term, highly liquid investments that are readily 
convertible to known amounts of cash and are not subject to a significant risk of changes in value. Cash equivalents are held for the purpose of meeting short-term liabilities and not for investment or other purposes. For an investment to meet the condition of being cash equivalent, it must be possible to convert it smoothly into a known amount of cash and it must be free from the risk of significant changes in value. Therefore, it is normally associated with investments in as a cash equivalent only when it has had a short maturity of, say, three months or less from the date of acquisition. Equity investments are exempt from cash equivalents unless they are substantially cash equivalents, for example in the case of the acquisition of preference shares that mature in the short term and have a specified redemption date.

\section{Classification of cash flows by activities}

According to IAS 7 - Statement of Cash Flows, all cash flows that the company realizes can occur as:

- cash flows from business (operational) activities,

- cash flows from investing activities i

- cash flows from financing activities.

This classification of activities enables the users of the Cash Flow Statement to:

- assessment of the impact of these activities on the financial position of the company and

- $\quad$ assess the relationship between the activities themselves.

Therefore, based on these activities, the share of cash inflows and outflows and cash equivalents of individual groups of activities in the total business is assessed, and based on that the contribution of individual activities to the overall financial result, while based on net cash flow it can be seen which activities had a positive, which has a negative effect on the final cash balance at the end of the period.

It should be noted that when classifying transactions, it is possible for cash flows caused by a single transaction to be classified in different ways. For example, in annuity payments, the installment amount is considered an outflow based on financing activities, and interest is considered an outflow based on business activities. 
It should be noted that the Statement of Cash Flows will not disclose those transactions that have a non-cash character, i.e. that do not have a direct impact on current cash flows, although they affect the capital structure and assets of the company. These are primarily investment and financing transactions that do not require the use of cash or cash equivalents, such as: conversion of short-term loans into long-term, conversion of long-term loans into equity, as well as movements between items representing cash or cash equivalents (e.g. money transfers from the cash register to the current account).

\section{Cash flows reporting in the Republic of Serbia}

According to the Law on Accounting of the Republic of Serbia from 2019, which came with its practical implementation on January 1, 2020, all legal entities and entrepreneurs registered in the Republic of Serbia have the obligation to compile all financial statements, including cash flow statements. The cash flow statement form is designed in accordance with IAS 7. Based on this, the following can be concluded:

- $\quad$ The prescribed scheme is compiled based on IAS 7;

- The direct method for compiling the Statement of Cash Flows was applied, except for certain items where net cash inflows and outflows are reported;

- There are 43 positions in the prescribed form, of which 23 are for cash inflows and outflows, and 20 for subtotals, exchange rate differences based on cash conversion and opening and closing balance of cash and cash equivalents.

\section{Analysis of Cash flows Report - theoretical and mehodological aspects}

Financial analysis is a detailed "research, quantification, description and assessment of the financial status and performance of the company". The subject of analysis is the financial statements, in particular, the annual report of the company, which contains: balance sheet, income statement, statement of cash flows, statement of changes in equity, notes and auditor's report. In addition to these mandatory elements of the annual report, other segments of the annual report, which are not mandatory, can be found as the subject of analysis. 
The objectives of the analysis of financial statements can be divided into general and specific objectives. [Knežević, 2009, 5] The general goal in and relating to the assessment of the ability of the income (viability, performance and profitability) companies and financial status (status) of the company, its cash flow and changes in capital in order to provide information to interested parties. Specific objectives are also aimed at meeting the information needs of stakeholders but these needs are specific depending on the interests of individuals. Managers, investors, employees, lenders, suppliers and other creditors, customers, governments, their agencies and the public appear as users of financial information. [Stojilković \& Krstić, 2000, 12]

Financial statements are a set of information about the financial position, performance, changes in capital and cash flows of a company and represent a functional and time-rounded set of business processes that have occurred in one company and as such, form the basis of any rational analysis. [Knežević, 2009, 9] In the practice so far, the Balance Sheet and the Income Statement have been analyzed most often, but in recent times the report on cash flows and the annex have been increasingly used as the subject of analysis.

Due to the different types of information provided by these financial statements, they are not alternative, but complementary. This practically means that all of them together are necessary for a complex review and assessment of the financial position and earning capacity of the company.

The Cash Flow Statement provides users with a detailed picture of transactions based on business, investment and financial activities and their impact on cash flows. The balance sheet and income statement are the basic sources of financial information. The balance sheet shows the financial position of the company at a given time, and the income statement the performance of the company for a certain period of time. However, users of accounting information are interested, among other things, in information on the company's solvency. Such information can also be obtained on the basis of the balance sheet, through ratios based on the ratio of assets and liabilities such as:

1. Quick liquidity ratio or

2. Rigorous (current) liquidity ratio

The disadvantage of these indicators is that they are based on the state of assets and liabilities in the past. These are static liquidity measures of 
companies based on the forced liquidation of assets and do not measure the current ability of a company to return from cash to cash. [Djukić, 2005, 164] Also, we cannot assess the company's solvency on the basis of the income statement, because the realized profit is not a guarantee that the company is able to pay due liabilities. Therefore, it is concluded that it is for the assessment of cash flows in the company as well as its liquidity and solvency need to analyze Cash Flow Statement, and as a starting point to take the cash flows not from business activities, because if the company achieves positive net cash flow from operating activities to mean "that the company is able to generate up to oil and cash to pay your accounts without lending. [Meigs \& Meigs, 1999, 396]

The analysis of the Cash Flow Statement is a dynamic analysis. Therefore, the analysis of the Cash Flow Statement, and above all the part related to cash flows from operating activities, can provide information on: [Pavlović, $2012,45]$

- The success of the company to generate cash from business activities.

- Trends in net cash flows.

- The main factors influencing positive or negative net cash flows.

\section{Methods and instruments of cash flows analyisis}

Cash flow analysis is based on the use of certain methods and instruments. The methods of analysis include two basic and two additional: [Djukić, 2005, 167]

- disaggregation method;

- comparison method;

- isolation method and

- synthesis method.

The method of disaggregation refers to the disaggregation of cash flows from the aspect of its sources, ie the activities that led to its generation. The usual breakdown of the Cash Flow Statement by its activities into: business, investment and financial activities. In this way, it is possible to see the contribution of each of these activities in achieving net cash flow (positive or negative). In addition to the basic breakdown of cash flows by activity, it is possible to break down cash flows into cash inflows and outflows; then by time (by semesters, quarters, months) or by subject. 
The comparison method compares individual items of the Cash Flow Statement in order to determine the positive or negative deviations of one subject of analysis in relation to another or the same subject but in two different periods. The comparison can be temporal and between companies. The time comparison may refer to the comparison of the Cash Flow Statement in two or more consecutive periods or to the comparison of the realized and planned cash flow statement. In order for a comparison between companies to be made, it is necessary to meet certain assumptions: 1) that the subject of analysis is the same phenomenon Cash Flow Statement; 2) that the comparison is made on the same day and 3) that the companies belong to the same branch. In this way, the position of the company in relation to other companies from the same branch, but also to the leader in the branch, is considered. Based on this analysis, it is assessed how far the company has come in its progress and whether there is room for further progress as well as how much effort needs to be invested in it.

The method of isolation implies a more detailed examination of a certain phenomenon, which can be of a positive or negative character, in order to discover the causes that led to that phenomenon. In this way, interested users come to information about the key factors that determine the business success of the company.

The synthesis method presents aggregate data from several consecutive periods that have previously been the subject of comparison. This method is important for considering the total cash flows of competitors and is used to compare the cash flows of the company with the industry average.

The instruments for the analysis of the Cash Flow Statement include: [Djukić, 2005, 64]

1. visual and

2. analysis using ratio numbers.

Visual analysis is one of the initial methods used in the analysis of financial statements. It is characterized by simplicity, which is why it is especially suitable for gaining a global picture of a company's cash flows. Data from the Cash Flow Statement are presented in the form of graphs in order to make assessments and general conclusions about the state and movement of cash in the company. 
Ratio analysis is one of the most commonly used instruments of financial analysis. In addition to the ratio analysis based on the basic financial statements (balance sheet and income statement), the ratio analysis based on the Cash Flow Statement has recently become increasingly important. Financial indicators based on cash flow can be divided into four groups: [Djukić, 2005, 64-67]

a) Liquidity and solvency ratios;

b) Profit quality indicators;

c) Capital expenditure indicators i

d) Cash flow return indicators.

a) Liquidity and solvency ratios speak of monetary coverage of interest, current liabilities, total liabilities and dividends. This group of indicators includes:

1. Coefficient of coverage of short-term liabilities (Current Cash Debt Coverage Ratio);

2. Cash Debt Coverage Ratio;

3. Cash Interest Coverage Ratio;

4. Cash Dividends Coverage Ratio.

The short-term liabilities coverage ratio represents the ratio between the net cash flow from operating activities and the short-term liabilities of the company. Net cash flow from operating activities is obtained as the difference between inflows and outflows from operating activities during the period. Short-term liabilities are the average value of short-term liabilities from the current and previous accounting period. The shortterm liability coverage ratio can be presented as follows:

$$
=\frac{\begin{array}{l}
\text { Coefficient of coverage of short }- \text { term liabilities with cash }= \\
\text { Net cash flows from operating activities }
\end{array}}{\text { Average short - term liabilities }}
$$

This ratio shows how much cash from business activities is covered by each monetary unit of short-term liabilities. A higher value of this coefficient shows that the company is operating successfully. Liquidity is considered satisfactory if the value of this ratio is $40 \%$. [Samuels, 1995, 17] 
The ratio of total cash coverage to liabilities shows the ratio between net cash flow from operating activities and total liabilities (including longterm provisions), and is calculated according to the following formula:

$$
\begin{gathered}
\text { Coefficient of coverage of total liabilities in cash }= \\
\text { Net cash flows from operating activities } \\
\text { Total liabilities }
\end{gathered}
$$

This coefficient shows the ability of the company to settle its obligations with the funds realized by performing business activities, ie. with how many monetary units of net cash flow from operating activities is covered by each monetary unit of liabilities. The preferred value of this coefficient is $20 \%$ and more. [Stickney \& Weil, 2000, 258]

The cash interest coverage ratio shows the ability of an enterprise to pay interest on its total debt. It is calculated as follows:

\section{Cash interest coverage ratio $=$}

$$
=\frac{\text { Net cash flows from operating activities }+ \text { interest paid }+ \text { taxes paid }}{\text { Interest paid }}
$$

There is no precisely determined value of this coefficient, but it is desirable to be greater than 1 . In the case when it is less than 1 , it would mean that the company fails to pay interest from the business, but for that it must obtain funds from external sources.

The cash dividend coverage ratio is of interest to shareholders and shows the company's ability to pay dividends from cash opportunities based on business activities. It shows how many monetary units realized on the basis of business activities of the company are covered by each monetary unit of paid dividends:

$$
\text { Cash dividend coverage ratio }=\frac{\text { Net cash flows from operating activities }}{\text { Dividens paid }}
$$

The value of this ratio must be greater than 1, otherwise the company must borrow to pay dividend liabilities and this is a bad signal to potential investors. [Mitchell et al. 1995, 59]

b) Profit quality indicators show the ratio of cash inflows from operating activities and sales revenues, as well as the ratio of cash inflows and profits. These indicators include: [Mitchell et al. 1995, 60] 
1. Quality of Revenues Ratio and

2. Quality of Earnings Ratio.

The sales quality ratioshows the relationship between cash inflows from sales and sales revenues. Based on it, it is possible to see what amount of sales revenue is collected or converted into cash during the accounting period:

$$
\text { Sales quality ratio }=\frac{\text { Cash inflows from sales }}{\text { Sales revenues }}
$$

The ideal situation would be for this ratio to be 1 , which would mean that everything sold during the period will be collected in the same period. Such a situation is achievable only in companies that sell their products for cash or charge for services in advance, in all other cases it is desirable that this coefficient weighs on the unit. [Sylvestre, 1994, 65]

Profit quality ratio shows the relationship between operating profit and net cash flow from operating activities:

$$
\text { Profit quality ratio }=\frac{\text { Operating profit }}{\text { Net cash flows operating activities }}
$$

or

$$
=\frac{\text { Profit quality ratio }=}{\text { Operating profit before interest and taxes }}
$$

This ratio is used to determine the discrepancy between the profit shown in the income statement and the net cash flows generated from operating activities, ie. to determine the percentage difference between the operating profit of the accounting period and the net cash flow from operating activities of the same period. [Sylvestre, 1994, 65]

Capital expenditure indicators link certain types of cash flows to assess the ability to acquire capital assets as well as financing and investment. This group of indicators includes: [Mitchell et al. 1995, 59]

1. Capital costs Ratio (Operating Cash Flow to Capital Expenditures Ratio); 
2. Investment outflows in relation to total outflows (Investing Outflow to Total Outflow);

3. The relationship between investment and business and financial activities (Investing to Operating and Financing);

4. The relationship between investment and financial activities (Investing to Financing).

The capital costs ratio aims to show the company's ability to service costs arising from capital expenditures:

$$
\text { Capital costs ratio }=\frac{\text { Net cash flows from operating activities }}{\text { Cash outflows for capital expenditures }}
$$

A stricter alternative to this ratio takes into account the company's obligation to shareholders, because the net cash flow from operating activities is used for investment purposes only after deducting funds intended for the payment of dividends:

$$
\begin{gathered}
\text { Capital costs ratio }= \\
=\frac{\text { Net cash flow from operating activities - dividens paid }}{\text { Cash outflows for capital expenditures }}
\end{gathered}
$$

If the value of the coefficient is equal to or greater than 1 , the company is able to generate sufficient funds to finance investments based on the performance of regular activities, otherwise the company must engage additional sources of financing.

Investment outflows in relation to total outflows are an indicator of the size of investments in new equipment and business organization, because insufficient investments of this type can lead to a weakening of the company's competitiveness and endanger its survival:

\section{Index of investment cash outflows in relation to total cash outflows =$$
=\frac{\text { Investment cash outflows }}{\text { Total cash outflows }}
$$

There is no defined value of this coefficient, but it is necessary to observe it in the context of temporal and spatial analysis, in order to gain insight into the existence of an investment strategy in modernization of production in order to strengthen the competitive position. 
The relationship between investment and business and financial activities indicates the share of financing investment activities from funds generated on the basis of business and financial activities:

$$
\begin{aligned}
& \text { Relationship between investment and financial activities }= \\
& =\frac{\text { Net cash flows from investing activities }}{\text { Net cash flows from financing activities }}
\end{aligned}
$$

If the value of this coefficient is 1 , it means that the entire amount of funds realized on the basis of financing activities is invested in investment activities. The reciprocal value of this coefficient shows how many monetary units realized on the basis of financial activities are covered by each monetary unit of investment activities.

Cash flow return indicators include: [Mitchell et al. 1995, 59]

1. Cash flow per share;

2. Cash Return on assets and

3. Cash Return on Stocholders Equity.

Cash flow per share is calculated using the following form:

$$
\begin{gathered}
\text { Cash flows per share }= \\
=\frac{\text { Net cash flow from operating activities }- \text { dividends paid on preferred shares }}{\text { Average number of ordinary shares }}
\end{gathered}
$$

This ratio is similar to the earnings per share ratio and shows how many units of net profit collected cover each share of ordinary shareholders.

Return on invested assets is the ratio between the net cash flow from operating activities and total assets. It provides information on the company's ability to generate a certain net cash flow based on the invested assets by performing business activities:

$$
\begin{gathered}
\text { Return on invested assets }= \\
=\frac{\text { Net cash flow from operating activities before interest and taxes }}{\text { Total assets }}
\end{gathered}
$$

The higher the value of this coefficient, the more successful the company is in generating cash flow with the help of invested funds, so the time 
period of return on invested assets from cash generated from operating activities will be shorter.

Return on equity shows the ability of the company to return the equity from the net cash flow from operating activities:

$$
\text { Return on equity }=\frac{\text { Net cash flows from operating activity }}{\text { Equity (share capital) }}
$$

Based on this ratio, we find out which part of the invested equity will be returned from the cash flow generated from business activities.

Free cash flow is a significant measure of the success of the company, which investors are very happy to use in the analysis of the attractiveness of the company's shares in the financial markets. This cash flow is defined as a measure of the balance of cash from operating activities when dividends are paid and when investments are made in the growth of the enterprise. They are obtained by the following formula:

Free cash flow $=$ Net cash flows from operating activities - Dividends - Net investments in fixed assets.

After performing the analysis of the Cash Flow Statement, it is possible to define the cash flow profile of the company. Depending on the results achieved on the basis of business, investment and financial activities, all companies can be classified into one of 8 profiles.

Table 1. The companies profile according to net cash flows from operating, investment and financial activities

\begin{tabular}{|cccc|}
\hline Profile & $\begin{array}{c}\text { Operating } \\
\text { activities }\end{array}$ & $\begin{array}{c}\text { Net cash flows } \\
\text { Investment } \\
\text { activities }\end{array}$ & $\begin{array}{c}\text { Financial } \\
\text { activities }\end{array}$ \\
\hline 1 & + & + & + \\
\hline 2 & + & - & + \\
\hline 3 & + & + & - \\
\hline 4 & + & - & - \\
\hline 5 & - & + & + \\
\hline 6 & - & - & + \\
\hline 7 & - & + & - \\
\hline 8 & - & - & - \\
\hline
\end{tabular}

Source: [Knežević, 2009, 142] 
In the first profile, the company generates positive cash flows from all three activities, most likely due to some larger investments in long-term assets in the future.

In the second profile, the company finances growth through business activities or through the issue of securities (shares, bonds) and borrowing. For that reason, in this profile, the cash flow based on investment activities is negative, while the sources of cash from business and financial activities are positive.

In the third profile, the company uses the positive cash flow from business and investment activities to pay dividends and to cover the principal of due long-term liabilities, so the cash flow from financial activities is negative, and positive from business and investment activities.

In the fourth profile, investment and financial cash flows are negative, while the flow from business activity is positive. This is the case of a company that finances the growth and repayment of dividends and principal from business activities. It is characteristic of companies that have been present on the market for many years and have stable production and sales.

In the fifth profile, net cash flow from operating activities is negative while it is positive based on investment and financial activities. Negative cash flow from operating activities is probably the result of difficulties in marketing products and services (falling demand). To compensate, the company intensifies the inflow based on financial and investment activities.

In the sixth profile, negative cash flows from business and investment activities are compensated by positive flows based on financial activities (issue of bonds, shares, etc.). This company invests in its growth and development and expects to lead to positive cash flows from business activities in the future. It is said that the business of companies from this profile is quite risky.

In the seventh profile, the company finances loan repayments, dividend payments and business activity with positive flows from investment activity (sale of long-term assets). This company is chronically illiquid and there is a significant risk of bankruptcy. 
In the eighth profile, cash flows from all activities are negative. This company is facing bankruptcy. There is an asynchrony and time mismatch of cash inflows and outflows based on all activities.

\section{Conclusion}

A cash flow statement is a financial statement that allows you to track money coming in and out of business. It is an integral part of the business and a great tool for managers, investors and other stakeholders that shows how changes in the balance sheet and income statement affect cash.

The Statement of Cash Flows explains what all during the reporting period affected the cash balance presented in the balance sheet at the beginning of the reporting period to arrive at a new cash balance at the end of the accounting period.Without information on the company's cash flows, it is not possible to make adequate business decisions and thus maximize the success of the activities undertaken.

Good methodology for analysing of the Cash flows is very important. Without that, information from the cash flows are more valuable. Just visual analysis is not enough for period of turbulent and uncertain conditions. The presented methodology can be used together with analyisng of Balance sheet and Income statement.

\section{Reference:}

Đukić, T. (2005). Bilans tokova gotovine kao instrument upravljanja likvidnošću preduzeća, (doktorska disertacija), Niš, Ekonomski fakultet;

IASC, Međunarodni računovodstveni standardi

IFRS: Ias 7 Statement of cash flows.

Kimmel, D.P., Weygandt J.J. \& Kieso, D.E. (2011). Financial Accounting, 6th edition, New Jersey;

Kintzele, P.E., (1990). Implementing SFAS95, Statement of cash flows, New York, The CPA journal, 1990 (02);

Knežević, G. (2009). Analiza finansijskih izveštaja, drugo izmenjeno i dopunjeno izdanje, Beograd, Univerzitet Singidunum;

Libby, R., Libby, A.P. \& Daniel, S.G. (2011). Financial Accounting, 7th edition, New York, McGraw-Hill. 
Meigs, R.F. \& Meigs, W.B. (1999), Računovodstvo - temelj poslovnog odlučivanja, Zagreb, Mate;

Mitchell, D.J., Goh, W.S. \& Stephen, S.C. (1995). A note on the relationship between reported cash flow measures, ratios and their accrual counterparts, New Zeland, Accounting and Finance 35 (1);

Pavlović, M. \& Bogdanović, J. (2013). Izveštavanje o tokovima gotovine, Novi Sad, Škola biznisa, 2013 (3-4);

Pavlović, M. (2012), Izveštavanje o tokovima gotovine preduzeća duvanske industrije u Republici Srbiji, (master rad), Niš, Ekonomski fakultet;

Samuels, M.J. (1995). Financial Statements Analysis in Europe, London, Chapman \& Hall;

Stančić, P. (2006). Izveštaj o tokovima gotovine, Beograd, Računovodstvo,, $50(3-4)$;

Stickney, P.C. \& Weil R.L. (2000). Financial Accounting, 9th edition, Orlando, Harcourt Inc;

Stojilković, M. \& Krstić, J. (2000). Finansijska analiza, Niš, Ekonomski fakultet;

Sylvestre J. \& Urbancic F.R. (1994). Effective methods for cash flow analysis, Healthcare Financial Management: Journal of the Healthcare Financial Management Association. 1994 Jul;48(7): 62;

${ }^{1}$ https://orcid.org/0000-0003-4112-6905

2 https://orcid.org/0000-0002-9847-0929

${ }^{3}$ https://orcid.org/0000-0002-6614-1055 


\title{
METODOLOGIJA ANALIZE IZVEŠTAJA O TOKOVIMA GOTOVINE
}

\author{
Miloš Pavlović ${ }^{1}$, Čedomir Gligorić ${ }^{2}$, Jana Cvijić Rodić ${ }^{3}$
}

1, 2, 3 Beogradska akademija poslovnih i umetničkih strukovnih studija, Beograd, Srbija

Korespondencija: milospavlovic84@hotmail.com ${ }^{1}$

Rezime: Novčani tokovi su jedan od glavnih pokazatelja likvidnosti i solventnosti preduzeća. U praksi se Izveštaj o tokovima gotovine vrlo često daje kao "dodatni dokument" uz bilans stanja i bilans uspeha. Ovo je pogrešno. Izveštaj o novčanim tokovima može korisnicima dati informacije o zarađivačkoj sposobnosti preduzeća. Bilans stanja i bilans uspeha, zbog svoje obračunske osnove, ne govore ništa o novčanim tokovima obračunskog perioda i zato je Izveštaj o novčanim tokovima veoma važan. Dobra analiza ovog izveštaja može biti osnova i podrška procesu donošenja odluka kako za interne, tako i za eksterne korisnike finansijskih informacija. U ovom radu predstavljamo metodologiju analize tokova gotovine. Predmet ovog rada je analiza Izveštaja o novčanim tokovima. Cilj ovog rada je da ukaže na značaj izveštavanja o novčanim tokovima i njegovim informacionim mogućnostima za korisnike računovodstvenih informacija.

Ključne reči: Metodologija, Novčani tokovi, Izveštaj o tokovima gotovine, Analiza novčanih tokova. 
